The current issue and full text archive of this journal is available on AFEBI Management and Business Review at:

https://journal.afebi.org/index.php/ambr/article/view/466

OWNERSHIP-RETENTION AND THE VALUE OF INDONESIAN INITIAL PUBLIC OFFERING (IPO) FIRMS IN 2013-2016

\author{
Ernie Hendrawaty*, Syifa Fadiah Adlina
}

Management, Faculty of Economics and Business, Lampung University, Indonesia

\begin{abstract}
The study investigates information asymmetry between security issuers and other market participants. Investors and entrepreneurs require reliable information about the firms. Therefore, it is crucial to examine how the top management information can be communicated to other market participants. The empirical implications of the model are tested on the set of 28 of 89 Indonesian firms that made an initial public offering in 2013-2016. The asymmetry problem is most significant when a firm makes a first public issue. Furthermore, the study explains the number of shares retained by the entrepreneur as a signal of IPO firm value. The test results are generally consistent with the signaling model's predictions, while the role of the controlling variables does not support the firm value.
\end{abstract}

Keywords: Ownership-Retention, Firm Value, Initial Public Offering, IPO.

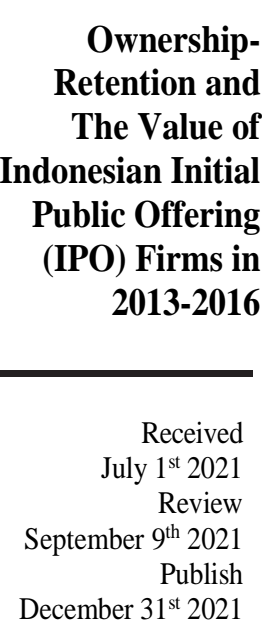

December $31^{\text {st }} 2021$

AFEBI Management and Business

Review

(AMBR)

P-ISSN 2548- 530X

E-ISSN $\underline{\mathbf{2 5 4 8 - 5 3 1 8}}$

*Corresponding author. Email address: ernie.hendrawaty@feb.unila.ac.id 
A company to develop its business must have a decision to increase capital, either by borrowing money or issuing shares in the capital market. The capital market is often used as alternative funding for companies with relatively low costs than debt. The first public offering transaction occurs in the primary market, and this activity is called the initial public offering or IPO (Widarjo, 2011).

The general objective is to develop its business, provide maximum prosperity to its shareholders, and optimize its value. The company's value is determined by the demand and supply of the shares concerned in the stock market (Faza and Hidayah, 2014). Firm value can be proxied by Tobin's Q ratio. Tobin's Q is an indicator to measure the company's performance, especially the value, which shows a management performance in managing company assets (Aida and Rahmawati, 2015). Firm value can be said to have a good performance if the average value of Tobin's Q ratio is more than one, and vice versa if the average value of Tobin's Q is less than one, then the firm value can be said to have a bad performance.

Ownership retention is the percentage of the old owner's shares that the old owners still retain after the company made an initial public offering (Widarjo, 2010). Initial public offerings have information that is not symmetric between the old owners of the company and shareholders. This imbalance of information can be minimized, so the old owner must convey a signal about the company's prospects to be offered to shareholders. The signal conveyed by the old owner will provide information to shareholders to find out the company's prospects in the future. According to Fan (2007), ownership retention can be measured by the number of new shares issued by the previous owner divided by the total number of shares issued after the IPO. Analyzing a problem in research can be easier by using control variables. The control variables used in this study were intellectual capital, leverage, and growth.

Intellectual Capital is all knowledge assets that are divided into stakeholder resources (relations stakeholder and human resources) and structural resources (physical infrastructure and virtual infrastructure) that contribute significantly to improving the competitive position by adding value to interest parties (Marr and Schiuma, 2004). Intellectual capital can be measured by the Value Added Intellectual Coefficient (VAIC) (Pulic, in Sayyidah and Saifi 2017). According to Sayyidah and Saifi, intellectual capital can be said well if the company can develop the ability to motivate their employees in order to make them innovative, increase productivity, and has a system also structure that can support the company for maintaining and even increasing the profitability and value of the company.

According to Hasibuan, Dzulkirom, and Endang (2016), company funds come from internal and external funds. Internal funds are sources of funds that originate from the company, such as retained earnings and depreciation, while external funds come from outside the company that obtained from suppliers, such as bank loans (loans) or leverage, securities (bonds), issuance of new shares, suppliers, creditors, and others. Leverage is the company's ability to meet its financial obligations both in the short and long term or measure the extent to which the company is financed with debt (Novari and Putu, 2016). Leverage can be measured using the Debt-toEquity Ratio (DER). Debt to Equity Ratio (DER) compares the total debt owned by the company to its own capital.

According to Sari and Abudanti (2015), large companies are more in demand than small companies, so that company's growth greatly affects the company's value. Furthermore, to rapid growth in managing growth, companies must have operational control, emphasizing cost control. Therefore, its faster growth can reflect the significant need for funds to expand its business and increase its desire to retain profits.

This research was conducted based on the inconsistency of the result from the previous studies, so further research is needed. Therefore, the above research is used as the basis by the author to research with the title " Ownership Retention and The Value Of Initial Public Offering (IPO) Firms In 2013-2016”.

\section{LITERATURE STUDY}

\section{Signaling Theory}

Signaling theory indicates that the company will try to show the signal in positive information to potential investors through disclosure in the financial statements (Miller and Whiting 2005). The signal theory states how a company should convey information signals obtained and valuable to investors to assess companies with good performance. The company's annual report is crucial information and can influence shareholders in decisionmaking. Signal theory starts from the assumption that each interested party does not get the same information. Unbalanced information about the company's prospects occurs between prospective shareholders and the company's former owners when conducting an initial public offering of shares in the capital market. The company owner certainly has much better information about the company's prospects than potential investors. Actions that the old owner of the company will take to communicate information to potential investors are called signals. A positive signal from the company can be expected to get a positive response from the market and provide competitive profits for the company and benefit investors. 


\section{METHODOLOGY}

This correlational research uses secondary data from the Indonesia Stock Exchange (IDX) database. The variables were from the Indonesian IPO's annual financial statements and prospectus reports in 2013-2016. The number of companies was 89 , while a number of samples were 28 companies according to predetermined criteria The dependent variable is firm value. The firm value is the shareholders' understanding of the company's level of success in managing resources, as seen in the company's share price. So, if the stock price is high, the company's value will be higher, and vice versa. Conversely, if the stock price is low, the company's value will be lower. Firm value is defined as market value because the company's value can provide maximum benefits for shareholders if the company's share price increases (Nurlela and Islahuddin, 2008). To measure the firm value, we use Tobin's Q. According to Lastanti (2004), Tobin's Q can be calculated using the following formula:

$$
\mathbf{Q}=(\mathbf{E M V}+\mathbf{D}) /(\mathbf{E B V}+\mathbf{D})
$$

Description:

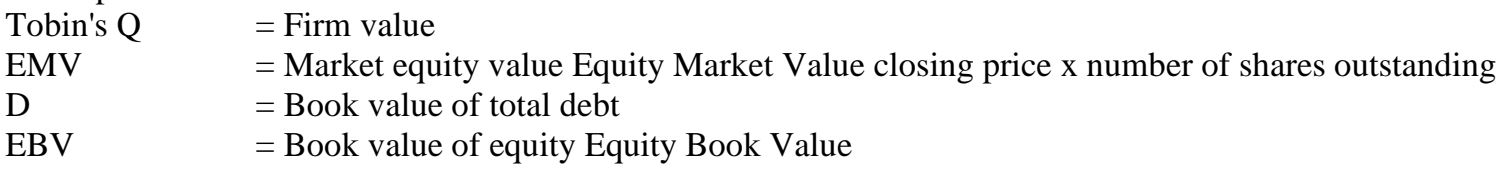

The primary independent variable is ownership-retention. The ownership-retention is the proportion of shares retained by the company after the IPO. Ownership-retention is the number of shares retained by the first owner of the shares that are still maintained until the company goes public, grouped in a percentage format. Ownership-retention is measured by the number of new shares issued after the previous owner divided by the total number of shares issued after the IPO (Fan Qintao, 2007), which can be formulated as follows:

\section{Ownership-Retention $=\underline{(\mathrm{N} \text { before }-\mathrm{N} \text { secondary })}$}

Description:

$\mathrm{N}$ before $\quad=$ Number of shares outstanding before the IPO

$\mathrm{N}$ secondary $\quad=$ Number of shares issued during the IPO

$\mathrm{N}$ after $\quad=$ Number of shares issued after the IPO

The other primary variable is intellectual capita. It can be interpreted as the distance between the value of the company and the cost of returning assets to company assets. Intellectual capital can be divided into three categories, namely knowledge related to employees (human capital), knowledge related to company partners (customer capital), and knowledge related only to companies (structural capital). Intellectual capital in this study is measured as follows:

a. Value-added (VA), namely the difference between output and input.

$$
\text { VA = OUT - IN }
$$

Description:

Output OUT $=$ Total sales and other income.

Input IN = Expenses and costs other than employee expenses

b. Value-added Capital Employed VACA, showing the contribution made by each unit of CE to the valueadded organizations.

$$
\mathrm{VACA}=\mathrm{VA} / \mathrm{CE}
$$

Description:

Value-added VA = Difference between output and input

Capital Employed CE = Funds available equity

c. Value-added Human Capital VAHU shows the contribution made by every rupiah invested in $\mathrm{HC}$ to the value-added organizations.

$$
\mathbf{V A H U}=\mathbf{V A} / \mathbf{H C}
$$

Description:

Value added VA

Human capital HC

$=$ Difference between output and input
$=$ Employee expense 
d. Structural Capital Value-added STVA measures the amount of SC needed to generate 1 rupiah from VA and is an indication of the success of SC in value creation.

\section{STVA $=$ SC/VA}

Description:

Structural Capital SC = Difference between value added and human capital

Value added VA $\quad=$ The difference between output and input

Human Capital HC $\quad=$ Employee expenses

e. Value-added Intellectual Coefficient VAIC, indicating the intellectual ability of the organization, which is calculated by the formula:

$$
\text { VAIC }=\text { VACA + VAHU + STVA }
$$

Statistical model of research to test the effect of ownership-retention and intelectual capital on the firm value is as follows:

Description:

$$
Y=\alpha+\beta_{1} X_{1} \beta_{1} X_{1}+\beta_{2} X_{2} \beta_{2} X_{2}+\beta_{3} X_{3} \beta_{3} X_{3}+\beta_{4} X_{4} \beta_{4} X_{4}+\varepsilon
$$

$\begin{array}{ll}\mathrm{Y} & =\text { Value Company } \\ \alpha & =\text { Constant } \\ \mathrm{X} 1 & =\text { Ownership Retention } \\ \mathrm{X} 2 & =\text { Intellectual Capital } \\ \mathrm{X} 3 & =\text { Leverage } \\ \mathrm{X} 4 & =\text { Growth } \\ \beta 1, \beta 2, \beta 3, \beta 4 & =\text { Regression coefficient (the value increases or decreases) } \\ \varepsilon & =\text { Error Term }\end{array}$

\section{RESULT AND DISCUSSION}

Descriptive statistics on each variable can be seen from Table 1 as follows:

Table 1.

Descriptive Statistics

\begin{tabular}{lccccc}
\hline & $\begin{array}{c}\text { Firm } \\
\text { Value } \\
(\mathrm{Y})\end{array}$ & $\begin{array}{c}\text { Intellectual } \\
\text { Capital } \\
(\mathrm{X} 1)\end{array}$ & $\begin{array}{c}\text { Ownership } \\
\text { Retention } \\
(\mathrm{X} 2)\end{array}$ & $\begin{array}{c}\text { Leverage } \\
(\mathrm{X} 3)\end{array}$ & $\begin{array}{c}\text { Growth } \\
(\mathrm{X} 4)\end{array}$ \\
\hline Mean & 1.91392 & 2.61642 & 0.53928 & 0.75535 & 0.69250 \\
Median & 1.42500 & 2.75000 & 0.53500 & 0.61500 & 0.45000 \\
Maximum & 4.50000 & 6.93000 & 0.93000 & 2.53000 & 2.52000 \\
Minimum & 0.21000 & -2.74000 & 0.05000 & 0.01000 & 0.30000 \\
Std. & 1.13232 & 2.44960 & 0.21874 & 0.61156 & 0.67899 \\
Deviation & & & & & \\
& & & & & \\
Observation & 28 & 28 & & & \\
\hline
\end{tabular}

Table 1 shows that the lowest firm value is 0.21 from Mega Manunggal Property Tbk (MMLP), which means that the company performance was poor because the company's value is less than 1 . So, it indicates that the company cannot maximize the market value. In this study, the maximum value was found in the Siloam International Hospitals Tbk (SILO) company, which was 4.50, meaning that this value indicated that the SILO company value was valued at four times greater than its book value. The mean value of the variable is 1.91 . Therefore, the mean value above shows that the sample company has a higher market value than its book value.

The ownership-retention (X1) variable shows that the ownership-retention of Blue Bird Tbk (BIRD) is the high have est, which means that the entrepreneur still maintains the company shares and has better information about the company. The minimum value is 0.05 from Bintang Oto Global Tbk (BOGA), which means that the company does not maintain the shares. The mean value of ownership retention is 0.53 , which means that companies in Indonesia were likely to maintain share ownership. 
The intellectual capital (X2) variable shows a minimum value of -2.74 from Siloam International Hospitals Tbk (SILO) company. The company is too small to provide information about its intangible assets, while intellectual capital must provide information about its intangible assets because it can affect its value. The mean value of the intellectual capital (X1) variable is 2.61. The mean value is good if the value is above 2.5 , or it can be categorized as bad companies (Sunarsih and Mendra, 2012).

The leverage (X3) variable shows the maximum value is 2.53 originated from Dharma Satya Nusantara Tbk (DSNG), which means the company has more debt or relies more on debt. The minimum value is 0.01 means that the most negligible total assets are financed by debt. The mean value is 0.75 , which means that the total assets financed by the company's debt are still relatively low and means that the company's total debt is smaller than its total assets so that the company's financial condition in this study is still relatively good.

The growth (X4) variable shows that Graha Layar Prima Tbk (BLTZ) has a value of 0.03, which means that the company is low growth because of the increasing uncontrollable costs. The maximum value is 2.52 were from Protech Mitra Perkasa (OASA). The mean value was 0.69 shows that, on average, the growth is still low.

The data of all the variables were estimated using the OLS model. The model tests the effect of ownership-retention, intellectual capital, leverage, and growth on the firm value.

\begin{tabular}{lrrr}
\hline & Variable & Coefficient & $\begin{array}{c}\text { t- } \\
\text { Statistic }\end{array}$ \\
\hline C & & 0.8193 & 1.0300 \\
Ownership-retention $\left(\mathrm{X}_{1}\right)$ & 2.6328 & 2.6696 & $* *$ \\
Intellectual Capital $\left(\mathrm{X}_{2}\right)$ & -0.1281 & -1.6571 \\
Leverage $\left(\mathrm{X}_{3}\right)$ & -0.5272 & -1.6118 \\
Growth $\left(\mathrm{X}_{4}\right)$ & 0.5895 & 1.7784 & $*$ \\
& & & \\
Observations & & 28 & \\
\hline R-squared & & & \\
Sum squared resid & 0.3661 & & \\
F-statistic & 21.942 & & \\
Prob (F-statistic) & 3.3215 & & \\
Durbin Watson stat & 0.0275 & & \\
\hline
\end{tabular}

Table 2 shows that the variable of ownership-retention has a probability value of 0.0137 ; therefore, the hypothesis is supported at the significance level of $5 \%$. The study support that ownership retention positively affects the value of Indonesian IPO companies in 2013 - 2016. The intellectual capital variable shows a probability value of 0.1111 , which means that intellectual capital does not affect on firm value of Indonesian IPO companies in 2013 - 2016. The controlling variables, the leverage, show a probability value of 0.1206 which means the leverage has no significant effect on firm value. Therefore, the role of leverage to increase the firms' value is not supported by this study. The other controlling variable, the growth, positively affects the value of Indonesian IPO firms for 2013 - 2016. So that, the hypothesis is supported in this study at the significance level of $10 \%$.

Retaining parts of its equity is a signal from the entrepreneurs to convince the investors about the firm and pay the value of its shares because the entrepreneur has superior knowledge about the firm's future performance. However, this signal is costly for entrepreneurs since it prevents them from holding an entire portfolio and exposes them to firm-specific risk..

\section{CONCLUSION}

Based on the results, it can be concluded that this study supports the signaling theory. This signaling theory will show a signal in the form of positive information. A positive signal from the company is expected to get a positive response from the market because this can provide a higher value for the company. According to Rock (1986), informed investors know more information about the company's prospects for buying or investing in IPO shares if the expected market price exceeds the initial price, and is supported by a prospectus or information issued by the company at the time of going public that gives a positive signal. It is concluded that this occurs because investors see their own more. The company also considers leverage and growth as control variables to control the influence of the independent variable on the dependent variable, even though the role of leverage is not significant to increase the value.

\section{Ownership- \\ Retention and \\ The Value of \\ Indonesian Initial \\ Public Offering \\ (IPO) Firms in \\ 2013-2016}

Table 2.

Test of $\mathrm{T}$

Statistics 
Agus, W. (2013). Ekonometrika pengantar dan aplikasinya. Ekonosia. Jakarta.

Aida, R. N., \& Rahmawati, E. (2015). Pengaruh modal intelektual dan pengungkapannya terhadap nilai perusahaan: Efek intervening kinerja perusahaan. Journal of Accounting and Investment, 16(2), 96-109.

Fan, Q. (2007). Earnings management and ownership retention for initial public offering firms: Theory and evidence. The Accounting Review, 82(1), 27-64.

Faza, M. F., \& Hidayah, E. (2015). Pengaruh intellectual capital terhadap profitabilitas, produktivitas, dan nilai perusahaan pada perusahaan perbankan yang terdaftar di Bursa Efek Indonesia (BEI). Ekbisi, 8(2).

Ghozali, I. (2016). Aplikasi Analisis multivariete dengan program IBM SPSS 23 (Edisi 8). Cetakan ke VIII. Semarang: Badan Penerbit Universitas Diponegoro, 96.

Hasibuan, V., Dzulkirom AR, M., \& Wi Endang NP, N. G. (2016). Pengaruh leverage dan profitabilitas terhadap nilai perusahaan (Studi pada perusahaan property dan real estate yang terdaftar di Bursa Efek Indonesia periode tahun 2012-2015). Jurnal Administrasi Bisnis, 39(1), 139-147.

Kasmir. 2014. Analisis Laporan Keuangan. Jakarta: PT Raja Grafindo Persada.

Kusumajaya, D. K. O. (2011). Pengaruh struktur modal dan pertumbuhan perusahaan terhadap profitabilitas dan nilai perusahaan pada perusahaan manufaktur di bursa efek Indonesia. Universitas Udayana, Denpasar: Tesis yang Tidak Dipublikasikan.

Lastanti, H. S. (2004). Hubungan Struktur Corporate Governance dengan Kinerja Perusahaan dan Reaksi Pasar. Konferensi Nasional Akuntansi: Peran Akuntan dalam Membangun Good Corporate Governance.

Marr, B., Schiuma, G., \& Neely, A. (2004). Intellectual capital-defining key performance indicators for organizational knowledge assets. Business Process Management Journal.

Miller, J.C., dan Whiting, R.H. 2005. "Voluntary Disclosure of Intellectual Capital and the "Hidden Value." AFAANZ Conference, Melbourne.

Novari, P. M., \& Lestari, P. V. (2016). Pengaruh ukuran perusahaan, leverage, dan profitabilitas terhadap nilai perusahaan pada sektor properti dan real estate (Doctoral dissertation, Udayana University).

Nurlela, R. dan Ishlahuddin. 2008. "Pengaruh Corporate Social Responsibility Terhadap Nilai Perusahaan dengan Presentase Kepemilikan Manajemen Sebagai Variabel Moderating”. Simposium Nasional Akuntansi XI Pontianak.

Pulic, A. (1998, January). Measuring the performance of intellectual potential in the knowledge economy. In 2nd McMaster Word Congress on Measuring and Managing Intellectual Capital by the Austrian Team for Intellectual Potential (pp. 1-20).

Sari, N., Ayu, K., \& Sudjarni, L. K. (2015). Pengaruh likuiditas, leverage, pertumbuhan perusahaan, dan profitabilitas terhadap kebijakan dividen pada perusahaan manufaktur di BEI (Doctoral dissertation, Udayana University).

Sayyidah, U., \& Saifi, M. (2017). Pengaruh Intellectual Capital Terhadap Nilai Perusahaan Dengan Profitabilitas Sebagai Variabel Moderasi (Studi Pada Perusahaan Sub Sektor Property Dan Real Estate Di Bursa Efek Indonesia Periode 2013-2015). Jurnal Administrasi Bisnis, 46(1), 163-171.

Sitanggang, Suartina. 2018. “Analisis Pengaruh Informasi Keuangan, Non Keuangan Serta Ekonomi Makro Terhadap Underpricing Pada Perusahaan Yang Melakukan IPO di Bursa Efek Indonesia (Studi Empiris pada Perusahaan Non Keuangan yang Listing di BEI 2013-2016).”

Sunarsih, N. M., \& Mendra, N. P. Y. (2012). Pengaruh modal intelektual terhadap nilai perusahaan dengan kinerja keuangan sebagai variabel intervening pada perusahaan yang terdaftar di Bursa Efek Indonesia. Simposium Nasional Akuntansi XV, 1(2), 2012.

Suryandani, A. (2018). Pengaruh pertumbuhan perusahaan, ukuran perusahaan, dan keputusan investasi terhadap nilai perusahaan pada perusahaan sektor property dan real estate. Business Management Analysis Journal (BMAJ), 1(1), 49-59.

Waluyo, T. M., Basri, Y. M., \& Rusli, R. (2015). Pengaruh Return on Asset, Leverage, Ukuran Perusahaan, Kompensasi Rugi Fiskal dan Kepemilikan Institusi Terhadap Penghindaran Pajak. Prosiding SNA 18 Medan, 1(1), 1-25.

Widarjo, W. (2010). Pengaruh ownership retention, investasi dari proceeds dan reputasi auditor terhadap nilai perusahaan dengan kepemilikan manajerial dan institusional sebagai variabel pemoderasi (Doctoral dissertation, UNS (Sebelas Maret University)). Widarjo, W. (2011). Pengaruh modal intelektual dan pengungkapan modal intelektual pada nilai perusahaan. Simposium Nasional Akuntansi XIV Aceh, 21 22.Widarjono, 